\title{
EVALUATION OF EXTERNAL FACTORS FOR THE DEVELOPMENT OF THE LATVIAN HEALTH SECTOR
}

\section{Daiga Behmane}

Mg. oec.

\section{Anita Villeruša}

Dr. med.

\section{Uldis Berkis}

Dr. oec.

\section{Didzis Rūtītis}

Dr. admin.

\begin{abstract}
The aim of the study is to determine the potential priorities for policy objectives and investment areas to improve the external environment of the health sector from the perspective of increasing the health service export capacity in Latvia. The health sector is relevant for internationalisation because of the permanently increasing demand in the course of cross-border health service provision, patient mobility and cross-border technological progress. Stable increase in exports of health services in Latvia is observed and the potential priorities for policy objectives and investment conditions need to be highlighted. The study evaluates external political, economic, social and technological factors relevant for the development of Latvian health care sector by applying the PEST analysis framework. The authors based on the analysis of literature and international studies derived PEST factors reflecting the external dimension of health sector taking into account the conceptual approach of increasing the competitiveness of the National Health Service providers. The rating of the PEST components was done by the expert method and by applying structured interviews for data collection. Experts were asked to rate the PEST factors from two aspects - significance and performance, by application the Likert scale (from 0 to 5). Experts $(n=20)$ represent the management of health care providers active in-service provision for international customers. The study reveals that national economic and technological environment factors have the greatest significance in the health sector business environment development, ranked 4.36 and 4.35 respectively, followed by social factors (4.23) and political factors (3.97). A stable economic environment is emerging as a major development condition reflecting the current situation in Latvia. As for the performance ranking, the lowest rate is assigned to political factor group (2.18) and particularly to the factors - long-term sector strategy, the government's timing and change, transparent sector legislation, public administration capacity
\end{abstract}


and sector employment policy. The low ranking of political factors' performance highlights the challenges of the health sector business environment political spectrum. The study confirms the technological advances of the sector, but also recognises that there are opportunities and space for increasing competition and room for the introduction of competing technologies in the Latvian health care market. The Latvian case justifies that the health sector is subject to substantial external imbalance and advantages of particular sector growth largely depend on the maturity of the external environment.

Keywords: Latvia, health care sector, competitiveness, external factors, PEST analysis

\section{Introduction}

The healthcare industry occupies an important place in the context of modern socioeconomic processes, globalisation and technological progress worldwide. Competitiveness of national health care providers can be characterised by their capacity to provide services to foreign patients thus revealing the capacity and attractiveness of the sector. The role of the competitiveness of the health system is challenged by the dual nature of its objectives, namely, health care as part of the national social protection system and health care as a dynamic, highly skilled workforce, technology and scientific potential driven economic sector. Increasing demand for health services due to population ageing and technological progress, as well as the citizens' mobility and demand for social convergence determine the growing proportion of health care in national economies and potentially creates new segments of the health care international market. The health care sector is specific, but also very relevant for internationalisation because of permanently increasing demand in the course of cross-border health service provision, patient mobility and cross-border technological progress.

Exports of healthcare services in Latvia are increasing steadily. Although in absolute terms being still a small (around EUR 2 million) proportion of the market, a stable increase is observed in the number of foreign patients. According to data collected by the alliance of 16 leading clinics "Baltic Care", more than 10000 foreign patients have received treatment in Latvia in 2016, which is 16.6 times more compared to 2011.

Medical export strategies are considerably affected by the global technological progress, but inside the EU increasingly by country's efficiency of public administration, economic and social factors, business environment and political agenda. According to the latest Global Competitiveness Index (2017/2018) Latvia ranks $54^{\text {th }}$ and the main factors negatively influencing the country's competitiveness are inefficient government bureaucracy, tax regulation, corruption and insufficiently skilled workforce. 
The aim of the study is to determine the potential priorities for policy objectives and investment areas to improve the external environment and performance of the health sector from the perspective of increasing the opportunity to provide medical service exports in Latvia.

\section{Methodology of Research}

The study evaluates external factors affecting the development of Latvian health care industry by applying the PEST analysis framework. Authors based on the analysis of literature, including the EC, WHO, WB, OECD, WEF publications and studies, derived PEST factors reflecting the external dimension of health sector

The rating of the PEST components was done by expert method and by applying structured interviews for data collection. Twenty experts representing ambulatory and hospital care from institutions of different ownership form (state, municipality and private) were identified from the "Registry of Medical institutions offering treatment services to foreign patients" run by the Health Inspectorate of Latvia. To compare the actual performance of the factor with the desired result, experts were asked to rank the PEST factors according to two aspects: (1) significance of the factor and (2) actual performance of the factor, both by application the Likert scale (from 0 to5). Significance and performance indicators for each of the factors were calculated and by further application of the GAP analysis, the performance level of each factor was calculated.

\section{Background: The importance of external factors in the functioning of the health system}

Organisation studies highlight the importance of understanding the wider meso- and macroeconomic environment in which organisations operate. Strategic analysis involves scanning a general or macroeconomic environment to identify and understand broader long-term trends and influences on business.

The importance of external factors for the development of health sector and health outcomes is highlighted in strategic documents of the European Commission, the World Health Organization and other international institutions.

Various research carried out confirms the importance of external factors in relation to successful operation of the health sector service providers to deliver efficient and high-quality health services and encourage economies to maximize their comparative advantage in productivity. As recognised 
by Lunt et al $(2014)^{1}$, the medical tourist industry is dynamic and volatile and a range of factors including the economic climate, domestic policy changes, advertising practices, geo-political shifts, and innovative and pioneering forms of treatment may all contribute towards shifts in patterns of consumption and production of domestic and overseas health services.

Studies demonstrate that external factors affect and define the parameters for micro-level activities. National government policies tend to be developed in isolation and are disconnected to micro-level capacity to meet patient preferences. The macro-micro integration of governance efforts is a critical issue in both high-income states, where medical institutions attempt to deploy substantial realignment efforts, and developing nations, which are lagging behind due to leadership weaknesses and lower levels of governmental investment (Bodolica et al., 2016). ${ }^{2}$

The framework model developed by the Irish National Competitiveness Council to analyse national competitiveness consists of three levels: (1) policy inputs; essential conditions for business competition, including productivity, process and costs, and labour supply; (3) sustainable growth at the top as an ultimate policy objective. It is acknowledged that specific national economic circumstances of the economy, such as the size of the market, import/ export capacity and presence of multinational firms play significant role in the set of metrics to be covered (Ketels, 2016) ${ }^{3}$.

\section{Selection of PEST factors}

As suggested by the OECD, economic development reform in Latvia should include health system reforms targeted at governance reforms for state-owned enterprises, productivity increase, transparent investment policy, human resource and infrastructure accessibility and cost efficiency $(\mathrm{OECD}, 2016)^{4}$.

Political factors are linked to the impact and opportunities provided by government attitudes towards the industry, changes in political institutions and the direction of political processes, legal issues and the general legislative environment.

The European policy for health and well-being Health 2020 highlights that real improvements in health can be achieved through better governance, broad-based political and cultural support ${ }^{5}$. It is recognised

\footnotetext{
1 Lunt, Smith, Exworthy, Green, Horsfall, Mannion (2014), OECD.

2 Bodolica, Spragon, Tofan (2016), Vol. 19, Issue 4; pp. 790-804.

3 Ketels (2016), Review of Competitiveness Frameworks.

4 OECD. (2016), Vol. 2016, Issue 1.

5 World Health Organization (2018a).
} 
that for the achievement of the strategic goals of Health2020, innovative new models of governance are required.

Political will, particularly in the form of high-level political support, was cited as the most important factor for the successful implementation of health policy in the recent study on evidence from practice in the process of the implementation of Health 2020 (WHO, 2018) ${ }^{6}$.

The health sector in Latvia has been affected substantially by fiscal and structural reforms due to recent economic crisis, which led to political rather than economically sound decisions ${ }^{7}$.

Whereas health remains largely a national matter, national health systems are being substantially shaped by the EU agenda. In future, the role of harmonized instruments to secure the social convergence in social outcomes of EU citizens will substantially increase ${ }^{8}$.

A study on Australian public health policy development has identified that the most influential stakeholder groups, acting as both barriers and facilitators, are the Minister and government, lawyers and other stakeholders, such as trade unions and employer groups (Zardo et al., 2014) $)^{9}$.

Economic factors relate to the economic structures of the society, the country's economic policy and capacity, tax and investment policies. Macro level refers to the financial capacity of health sector. Budgetary constraints affect the sector's production capacity directly. Financial stability of the economy is critical to provide capital for investments and to shift health risks among individuals and society.

As preconditions for achieving efficiency and affordability under regulated competition in health care, are suggested factors arising from the external environment, such as risk-bearing buyers and sellers, contestable markets, freedom to contract and integrate, effective competition regulation, effective quality supervision. It is emphasised that there ought to be no necessary barriers to enter or exit the market. Government subsidies for public hospitals or financial support to failing hospitals reduce the competitive advantage of efficient firms (Van den Ven et al., 2013) ${ }^{10}$.

Government regulations have economic consequences. Not always the costs of the implementation of regulations and doing business are considered. As suggested by the World Bank's Doing Business ranking,

\footnotetext{
6 World Health Organization (2018b).

7 Taube, Mitenbergs, Sagan (2014).

8 European Commission (2017), Reflection Paper on the Social Dimension of Europe.

9 Zardo, Collie, Livingstone (2014), pp. 120-127.

${ }^{10}$ Van den Ven, Beck, Buchner, Schokkaert, Schut, Shmueli, Wasem (2013), pp. 226-245.
} 
efficiency of the regulation process has to be considered. The health sector along with the need for substantial investments is sensitive to the costs caused by specific public regulations.

It is recognised that improvements in health system outcomes are stimulated by not only the total expenditure on health and a lower financial burden on patients, but primarily are determined by the broader economic context of the country (Romaniuk, Szromek, 2016) ${ }^{11}$. The JEL (Journal of Economic Literature) classification suggests to classify economic factors that influence health in categories, such as market regulation, institutions, supply of money, finance and loans, the balance between the public, private and third sector, labour, production and consumption and approaches to the economy (Naik et al, 2017).

Production factors play significant role for the development of economies. Several studies conclude that human resources is critical in providing high quality of health care and achieve better outcomes (Kabene et al, 2006) ${ }^{12}$, (Dubois et al, 2006) ${ }^{13}$. By considering the negative tendencies of demography and migration in Latvia, the issue of labour supply and productivity becomes crucial for the health care industry. Until now, improvement of Latvian competitiveness was determined by reducing labour costs. To maintain the advantages of low cost labour in long term will not be possible under conditions of labour market liberalization and international mobility of the workforce (Mavlutova, Titova, 2013). ${ }^{14}$

Social factors are connected with shared values, cultural attitudes, ethical beliefs, demographics, educational levels, etc. Observing social factors helps organisations maintain their relevance and attractiveness in the eyes of citizens and society as a whole.

Management models are to be found that allow the implementation of principles and values protected in the society such as accountability and responsiveness in accordance with communities' interests (Rechel et al, 2009) $)^{15}$.

The term accountability refers to the need to make decision process in healthcare visible and transparent. Democratic accountability refers to the process by which the healthcare institutions from Government to individual providers account to society. The different accountability levels

\footnotetext{
${ }^{11}$ Romaniuk, Szromek (2016), pp. 16-95.

12 Kabene, Orchad, Howard, Soriano, Leduc (2006).

${ }^{13}$ Dubois, McKee, Nolte, (2006).

${ }^{14}$ Mavlutova, Titova, (2013), pp. 1063-1072

${ }^{15}$ Rechel, Wright, Edwards, Dowdeswell, McKee (2009).
} 
are related to the different types of society's participation in democratic process (Nunes et al, 2011) ${ }^{16}$.

Technological factors are linked to changes in technology that can change the provider's competitive position, improvement of current products and process innovations that can reduce production costs. Management innovation is part of the technological progress.

As recognised, technology drives healthcare more than any other force, and in the future, it will continue to develop in dramatic ways (Thimbleby, 2013) $)^{17}$.

Technological advance in health care relate to the progress in medical technologies, the ways of service production, readiness of support and communication systems, as well as a company's ability to operate in the global medical knowledge exchange environment. Health care organisations usually compete for prestige equipment, even if not always economically justified.

Technological progress is assumed to boost health care costs, but studies suggest that the relationship between medical technology and spending is complex and often conflicting, especially if additional benefits resulting from the use of the technology, such as effective, cost-effective, and higher quality health care, justify increase in costs (Sorenson et al, 2013 $)^{18}$.

The summary of external factors relevant to health care sector is depicted in Table 1.

Taking into account that Latvia's public expenditure on health is very low, at $5.5 \%$ of GDP, and only $8.8 \%$ of public expenditure is spent on health, compared to $15.1 \%$ across OECD countries ${ }^{19}$, private health care is well underway. This explains that there is room for the development of private healthcare provision and consequently private providers are active in attracting external patients to secure business profitability.

\footnotetext{
${ }^{16}$ Nunes, Brandao, Rego (2011), pp. 352-364

17 Thimbleby (2013). Vol. 2, No 3, e28.

${ }^{18}$ Sorenson, Drummond, Bhuiyan Khan (2013). pp. 223-234.

${ }^{19}$ OECD. (2017).
} 
Table 1. External factors relevant to the health sector PEST analysis

\begin{tabular}{|c|l|c|l|}
\hline \multicolumn{2}{|c|}{ POLITICAL FACTORS } & \multicolumn{2}{c|}{ ECONOMIC FACTORS } \\
\hline 1.1 & $\begin{array}{l}\text { Comprehensive and transparent } \\
\text { sector legislation }\end{array}$ & 2.1 & Stable home economy trends \\
\hline 1.2 & International legislation & 2.2 & $\begin{array}{l}\text { Competition between service } \\
\text { providers }\end{array}$ \\
\hline 1.3 & Public administration capacity & 2.3 & Encouraging state investment policy \\
\hline 1.4 & Capacity of regulatory bodies & 2.4 & Supportive tax policy \\
\hline 1.5 & $\begin{array}{l}\text { Existence of long-term sector } \\
\text { strategy }\end{array}$ & 2.5 & Consumer purchasing power \\
\hline 1.6 & Government term and change & 2.6 & Sustainable financing mechanism \\
\hline 1.7 & Sector employment policies & 2.7 & Labor productivity, supply and costs \\
\hline \multicolumn{2}{|c|}{ SOCIAL FACTORS } & & \multicolumn{1}{|c|}{ TECHNOLOGICAL FACTORS } \\
\hline 3.1 & Lifestyle trends & 4.1 & Technological progress \\
\hline 3.2 & Demographics (age, growth) & 4.2 & Threats from competing technology \\
\hline 3.3 & $\begin{array}{l}\text { Population adherence to health } \\
\text { system }\end{array}$ & 4.3 & Innovation in service provision \\
\hline 3.4 & Informed and demanding customers & 4.4 & Research funding by government \\
\hline 3.5 & Accountable advertising and publicity & 4.5 & $\begin{array}{l}\text { Available ICT support and data } \\
\text { exchange systems }\end{array}$ \\
\hline 3.6 & Consumer buying patterns & 4.6 & $\begin{array}{l}\text { High standards for the protected } \\
\text { health information }\end{array}$ \\
\hline 3.7 & $\begin{array}{l}\text { Employment patterns, attitude to } \\
\text { work }\end{array}$ & 4.7 & International knowledge transfer \\
\hline
\end{tabular}

Source: Developed by authors.

As for the care level, according to the alliance "Baltic Care" information mostly foreign patients are interested in receiving short-term care, which is provided in ambulatory setting. Therefore, health care export services in Latvia are provided mainly by private health care institutions and in ambulatory setting, which is reflected in the structure of experts represented in the study (see Table 2). 
Table 2. Expert characteristics by represented care level and institution's ownership form $(n=20)$

\begin{tabular}{|c|c|}
\hline \multicolumn{2}{|c|}{ Care level } \\
\hline ambulatory care & 14 \\
\hline hospital care & 6 \\
\hline Ownership & 3 \\
\hline state & 5 \\
\hline municipality & 12 \\
\hline private
\end{tabular}

Source: Developed by authors.

\section{Results and discussion}

\section{Evaluation of POLITICAL factors}

In the group of political factors (see Table 3), the highest importance is assigned to the creation of an environment for the introduction of international requirements for the health sector, factor international legislation (4.45), thus pointing to the growing impact of international regulation and practice on health system operation on national level. Longterm sector strategy and sector employment policy (ranked 4.3 and 4.25) are mentioned as next most important external factors affecting sustainable health sector growth.

Table 3. Expert-assigned mean values for POLITICAL factors

\begin{tabular}{|c|c|c|c|c|}
\hline 1 & POLITICAL FACTORS & $\begin{array}{l}\text { Significance } \\
\quad(0-5)\end{array}$ & $\begin{array}{c}\text { Performance } \\
(0-5)\end{array}$ & $\begin{array}{c}\text { Performance, } \\
\%\end{array}$ \\
\hline 1.1 & $\begin{array}{l}\text { Comprehensive and transparent } \\
\text { legislation }\end{array}$ & 4.2 & 2.2 & 52.38 \\
\hline 1.2 & International legislation & 4.45 & 2.4 & 53.93 \\
\hline 1.3 & Public administration capacity & 3.45 & 2.2 & 63.77 \\
\hline 1.4 & Capacity of regulatory bodies & 3.55 & 2.5 & 70.42 \\
\hline 1.5 & Long-term sector strategy & 4.3 & 1.75 & 40.70 \\
\hline 1.6 & Government term and change & 3.6 & 2 & 55.56 \\
\hline \multirow[t]{2}{*}{1.7} & Sector employment policies & 4.25 & 2.2 & 51.76 \\
\hline & Mean value & 3.97 & 2.18 & 54.86 \\
\hline
\end{tabular}


The lowest performance level is assigned to the factor long-term sector strategy (1.75) comprising only $40.70 \%$ from the expected score, which reveals that health sector stakeholders have low awareness of longterm sectoral policy and is considered as major external threat for the development. Next lowest rank in performance is given to the government's timing and change (2.0), which reflects that frequent changes in Latvian government and the subsequent frequent changes in sectoral policy are significant obstacles for the sector growth. Further factors hindering the development of the sector are mentioned: transparent sector legislation (2.2.), public administration capacity (2.2) and sector employment policy (2.2.).

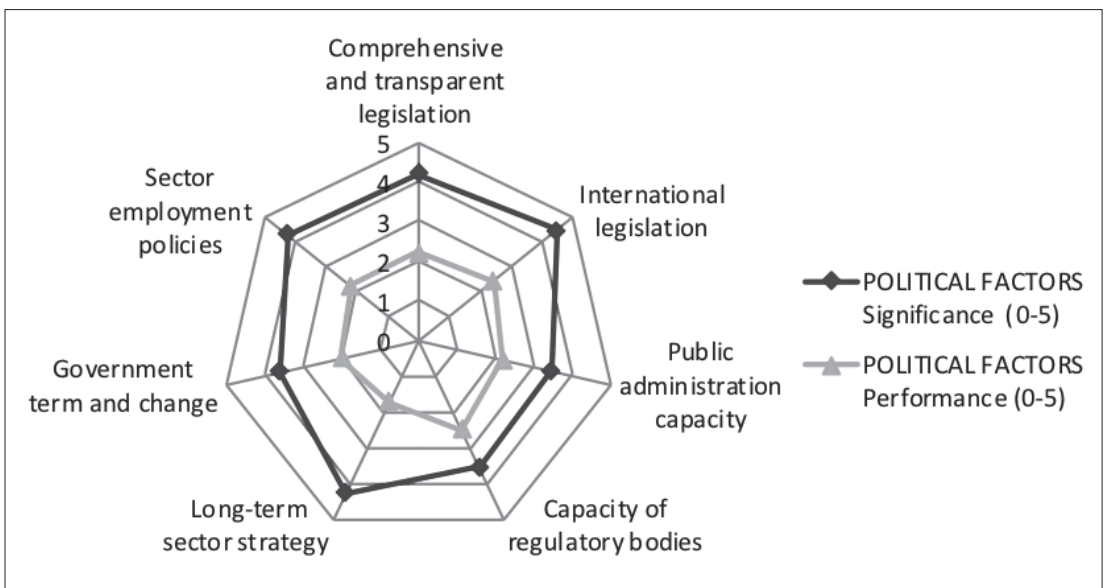

Figure 1. Significance and performance of POLITICAL factors (0-5, Likert scale)

Although the overall importance of the Political factor group is rated at the level of 3.97, which is slightly lower than other factor groups, the performance of the group is rated considerably lower than the rest of the groups (54.86\%), which is threatening for sustainable business environment.

\section{Evaluation of ECONOMIC factors}

Economic factors (see Table 4) are ranked as the most significant factor group (mean value of the group - 4.36) with the highest ranking for consumer purchasing power (4.8), followed by labour productivity, supply and costs (4.65) and sustainable financing mechanisms (4.55). 
Table 4. Expert-assigned mean values for ECONOMIC factors

\begin{tabular}{|c|c|c|c|c|}
\hline 2 & ECONOMIC FACTORS & $\begin{array}{c}\text { Significance } \\
(0-5)\end{array}$ & $\begin{array}{l}\text { Performance } \\
\quad(0-5)\end{array}$ & $\begin{array}{c}\text { Performance, } \\
\%\end{array}$ \\
\hline 2.1 & Stable home economy trends & 4.3 & 2.8 & 65.12 \\
\hline 2.2 & $\begin{array}{l}\text { Competition between service } \\
\text { providers }\end{array}$ & 4.1 & 3.65 & 89.02 \\
\hline 2.3 & Encouraging state investment policy & 4.1 & 1.9 & 46.34 \\
\hline 2.4 & Supportive tax policy & 4 & 2 & 50.00 \\
\hline 2.5 & Consumer purchasing power & 4.8 & 2.95 & 61.46 \\
\hline 2.6 & Sustainable financing mechanism & 4.55 & 1.95 & 42.86 \\
\hline \multirow[t]{2}{*}{2.7} & Labor productivity, supply and costs & 4.65 & 3.1 & 66.67 \\
\hline & Mean value & 4.36 & 2.62 & 60.16 \\
\hline
\end{tabular}

In the performance dimension least evaluated are factors: encouraging state investment policy (1.9), sustainable financing mechanisms (1.95) and supportive tax policy (2). At the same time, the performance of indicator labour productivity, supply and costs is scored higher (3.1) than the reported situation in Latvia in general, which can be explained by the composition of the surveyed, the majority representing private health care providers, for whom the retention of workforce is not so an acute problem as for public institutions.

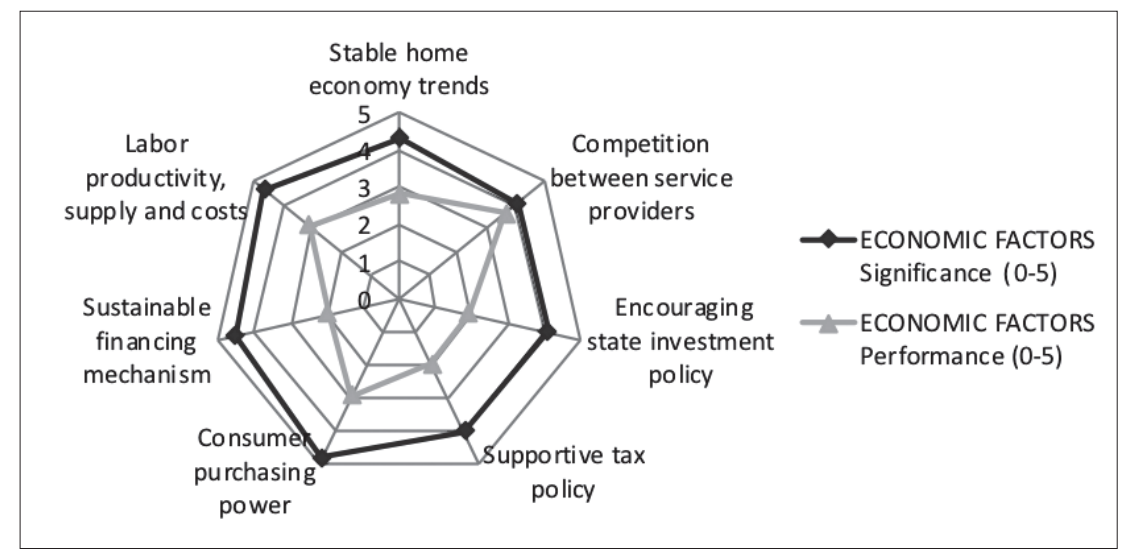

Figure 2. Significance and performance of ECONOMIC factors (0-5, Likert scale) 
The biggest gap between the significance and performance is attributed to the indicators sustainable financing mechanisms (42.86\%), encouraging state investment policy (46.34\%) followed by supportive tax policy $(50.00 \%)$. Thus showing the system's dependence on sustainable financial security.

\section{Evaluation of SOCIAL factors}

Overall the experts have evaluated the importance of social factors (see Table 5) slightly lower (4.23) than economic and technological factors. The highest rank in social factor group is attributed to accountable advertising and publicity (4.5) highlighting the importance of accountable communication and public relation tools in health sector development.

Table 5. Expert-assigned mean values for SOCIAL factors

\begin{tabular}{|c|c|c|c|c|}
\hline 3 & SOCIAL FACTORS & $\begin{array}{c}\text { Significance } \\
(0-5)\end{array}$ & $\begin{array}{l}\text { Performance } \\
\quad(0-5)\end{array}$ & $\begin{array}{c}\text { Performance, } \\
\%\end{array}$ \\
\hline 3.1 & Lifestyle trends & 4 & 3 & 75.00 \\
\hline 3.2 & Demographics (age, growth) & 4 & 3.1 & 77.50 \\
\hline 3.3 & $\begin{array}{l}\text { Population adherence to health } \\
\text { system }\end{array}$ & 4.35 & 2.95 & 67.82 \\
\hline 3.4 & Informed and demanding customers & 4.45 & 3.15 & 70.79 \\
\hline 3.5 & Accountable advertising and publicity & 4.5 & 3 & 66.67 \\
\hline 3.6 & Consumer buying patterns & 3.9 & 3.05 & 78.21 \\
\hline \multirow[t]{2}{*}{3.7} & $\begin{array}{l}\text { Employment patterns, attitude to } \\
\text { work }\end{array}$ & 4.4 & 2.9 & 65.91 \\
\hline & Mean value & 4.23 & 3.02 & 71.45 \\
\hline
\end{tabular}

The factor informed and demanding customers (4.45) is considered to be a significant factor in health service provision thus emphasising the emerging trend of patient centred health care and the importance of patient compliance. Employment patterns and attitude to work (4.4.) tend to form the social environment of the employment and customer relationship being valued highly in the health sector. 


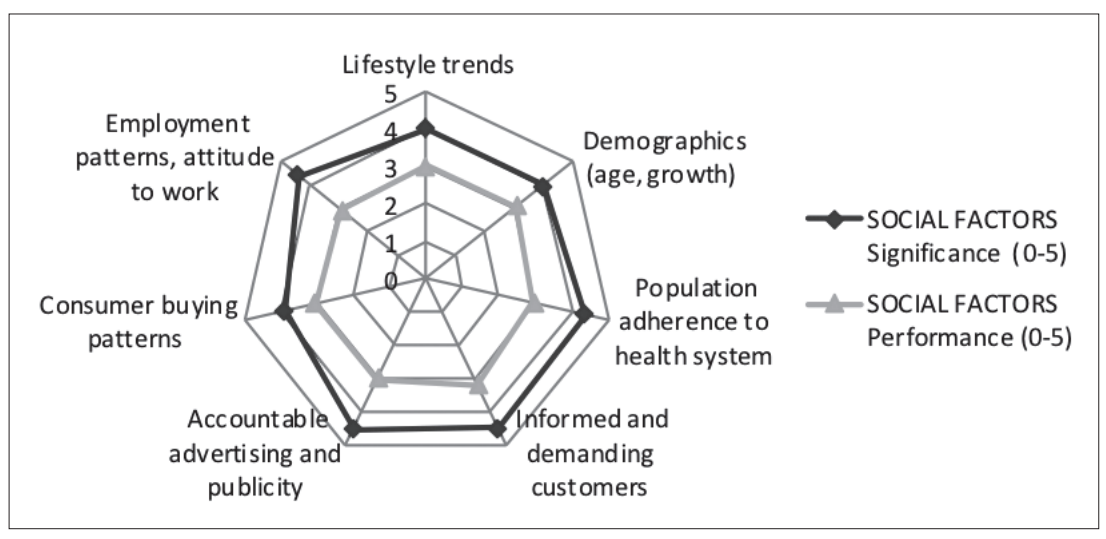

Figure 3. Significance and performance of SOCIAL factors (0-5, Likert scale)

In the social factor group, overall performance rating is higher (71.45\%) than in other factor groups highlighting that social factors are posing a lower threat to the development of the health sector than political, economic and technological factors.

\section{Evaluation of TECHNOLOGICAL factors}

The expert evaluations (see Table 6) indicate that technological advancement of the sector is of paramount importance for ensuring a competitive edge. Technological progress itself is ranked as most important technological factor (4.8) among all, followed by ICT support (4.6), international knowledge transfer (4.55) and innovation in service provision (4.5). Somewhat lagging behind is the ranking of the significance factor threats from competing technology (3.95) characterising the modest competition level between health care providers. Performance of the technological progress is ranked high (3.85) meaning that the provision of health care services is ensured by high technological support in Latvia. In the performance dimension the lowest ranks are attributed to available research funding (1.65) and implementation of high standards for health information provision and ICT support, thus depicting the potential areas for improvement in technological area - the need for a comprehensive research strategy supported and evidence-based selection of technologies applied, including information exchange platforms, e-health system and other ICT tools. 
Table 6. Expert-assigned mean values for TECHNOLOGICAL factors

\begin{tabular}{|c|c|c|c|c|}
\hline 4 & TECHNOLOGICAL FACTORS & $\begin{array}{l}\text { Significance } \\
\quad(0-5)\end{array}$ & $\begin{array}{l}\text { Performance } \\
\quad(0-5)\end{array}$ & $\begin{array}{c}\text { Performance, } \\
\%\end{array}$ \\
\hline 4.1 & Technological progress & 4.8 & 3.85 & 80.21 \\
\hline 4.2 & Threats from competing technology & 3.95 & 2.85 & 72.15 \\
\hline 4.3 & Innovation in service provision & 4.5 & 3.4 & 75.56 \\
\hline 4.4 & Research funding by government & 3.9 & 1.65 & 42.31 \\
\hline 4.5 & ICT support & 4.6 & 2.8 & 60.87 \\
\hline 4.6 & $\begin{array}{l}\text { High standards for health } \\
\text { information }\end{array}$ & 4.15 & 2.35 & 56.63 \\
\hline \multirow[t]{2}{*}{4.7} & International knowledge transfer & 4.55 & 3.1 & 68.13 \\
\hline & Mean value & 4.35 & 2.86 & 65.68 \\
\hline
\end{tabular}

The gap analysis for technological factors reveals that health care organisations depend on the overall research environment in the industry and the growth strategies should be based on evidence and research-based assumptions.

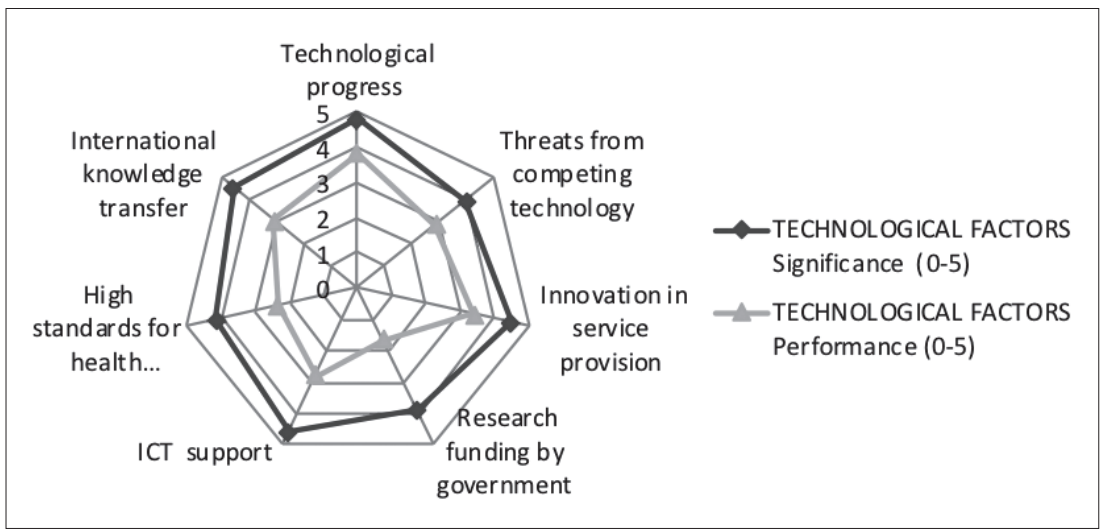

Figure 4. Significance and performance of TECHNOLOGICAL factors $(0-5$, Likert scale)

The health care managers also attribute the slow introduction of national e-health system as a threat to the competitive environment accompanied by the need for overall surveillance of high standards for health information. 
The results of external factor evaluation by experts reveals that national economic and technological environment factors have the greatest significance in the health sector development, ranked 4.36 and 4.35 respectively, followed by social factors (4.23) and political factors (3.97). In relation to the actual performance of external factors, the performance of political factors has been assessed to be the lowest (2.81), but the most relevant - the compliance of social factors (3.02).

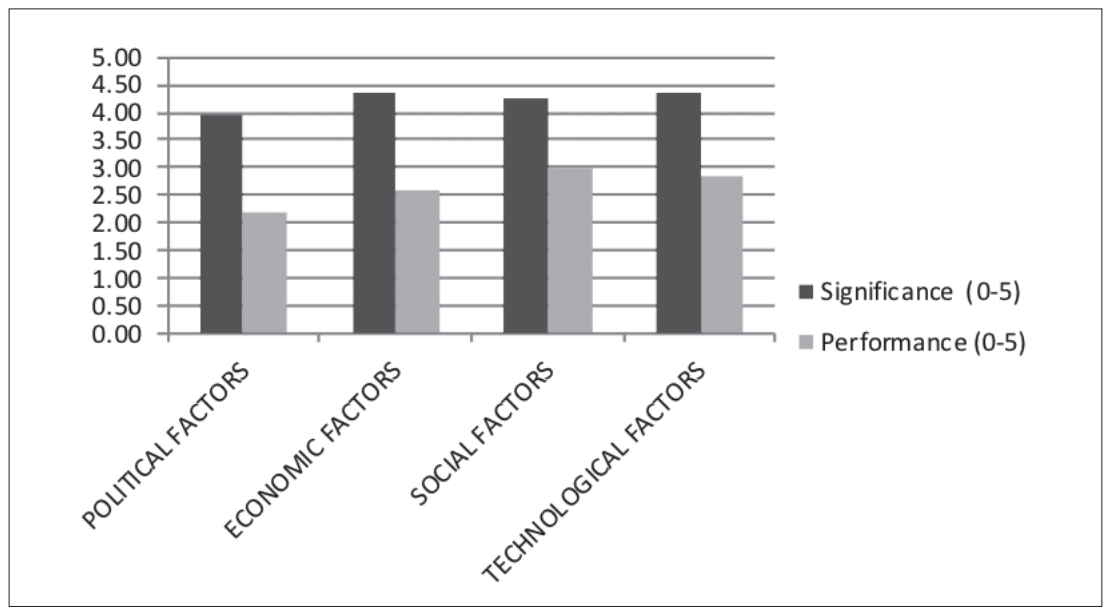

Figure 5. Significance and performance of PEST factor groups (0-5, Likert scale)

The difference between the attributed significance and real performance of the factor reveals (see Table 7) that political factors have the biggest gap in real performance, estimated only at $54.86 \%$ level, followed by economic factors $(60.16 \%)$, technological factors $(71.45 \%)$ and social factors $(71.45 \%)$.

Table 7. Performance of the PEST factor groups as $\%$ from the mean significance values, the GAP analysis

\begin{tabular}{|l|c|}
\hline & $\begin{array}{c}\text { Performance of the PEST group as \% } \\
\text { of the significance values }\end{array}$ \\
\hline POLITICAL FACTORS & 54.86 \\
\hline ECONOMIC FACTORS & 60.16 \\
\hline SOCIAL FACTORS & 71.45 \\
\hline TECHNOLOGICAL FACTORS & 65.68 \\
\hline
\end{tabular}


To determine the greatest threats to the development of the sector and the resulting health policy priorities, the factors were grouped (see Figure 6) according to the ranked performance indicators. Performance ranked as 4 and 5 is considered as good, 2, 5-3 - as moderate and 1 and $2-$ as poor.

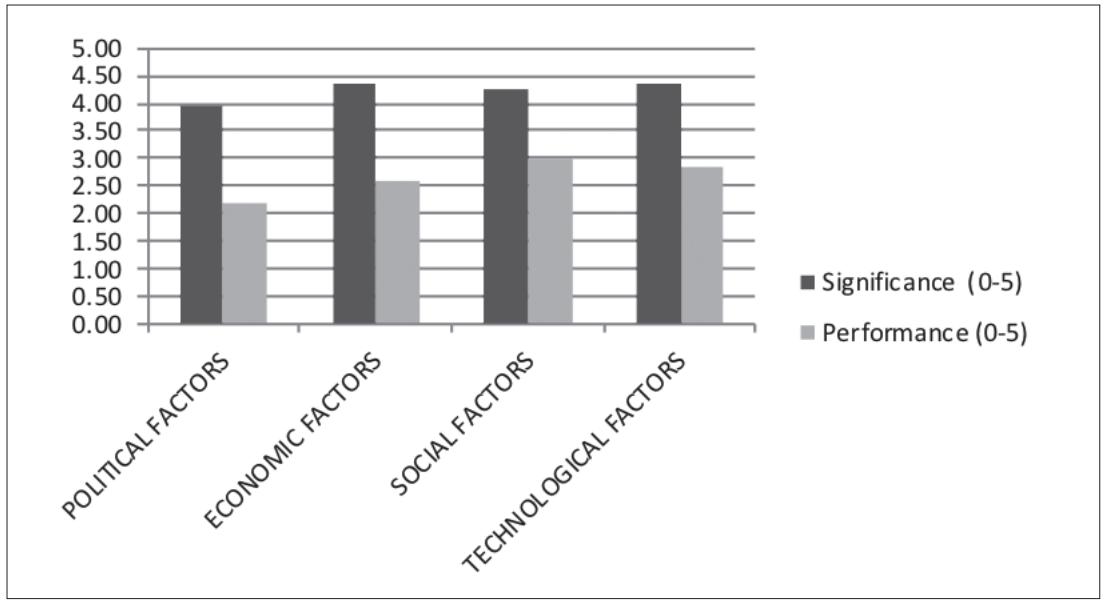

Figure 6. Significance and performance of the PEST factor groups (Likert scale 0-5)

The assessment has identified that the main external threats to the sustainable development of the health sector in Latvia are (factors with a poor performance rated by 2 or below): lack of long-term sector strategy (1.75), government term and change (2.0), vague state investment policy (1.9), lack of sustainable financing mechanism (1.95), lack of supportive tax policy (2.0) and low research funding by government (1.65).

\section{Conclusions}

The PEST analysis adds value to the evaluation of the external environment of the health sector in Latvia. The study shows that the success of health care organisations' development is significantly dependent on the external political, economic and technological, but slightly less from the social environment factors. Sustainability of the PEST-defined environment is crucial for investment decisions indicating that without facilitating economic conditions and clear political direction, investments may also be inappropriate for long-term strategic sector development. 
International requirements also have a considerable impact on the future development of national health systems.

The study justifies technological advances of the sector, but also recognises that there are opportunities and space for increasing competition and room for the introduction of competing technologies in the Latvian health care market.

The Latvian case justifies that health sector is subject to substantial asymmetric external imbalance and available advantages of particular sector growth largely depend on the maturity of the external environment.

\section{REFERENCES}

1. Bodolica, V., Spragon, M., Tofan, G. (2016). A structuration framework for bridging the macro-micro divide in health-care governance. Health Expectations, Vol. 19, issue 4; pp. 790-804.

2. Dubois, C., McKee, M., Nolte, E. (2006). Human Resources for Health in Europe, European Observatory, Open University Press.

3. European Commission. (2017). Reflection Paper on the Social Dimension of Europe. Available online: https:/ec.europa.eu/commission/sites/beta-political/files/ reflection-paper-social-dimension-europe_en.pdf.

4. Ketels, Ch. (2016). Review of Competitiveness Frameworks. An analysis conducted for the Irish National Competitiveness Council. Available online: https:// www.researchgate.net/publication/303522738_Review_of_Competitiveness_ Frameworks.

5. Kabene, S., Orchad, C., Howard, J., Soriano, M., Leduc, R. (2006). The importance of human resources management in Health care: a global concept. Human Resources for Health, https://doi.org/10.1186/1478-4491-4-20.

6. Lunt, N., Smith, R., Exworthy, M., Green, S. T, Horsfall, D., Mannion, R. (2014). Medical Tourism: Treatments, Markets and Health System Implications: A scoping review. Directorate for Employment, Labour and Social Affairs, OECD.

7. Mavlutova, I., Titova, S. (2013). Economic Environment Impact on Pension System: Case of Latvia. Procedia - Social and Behavioral Sciences 110, pp. 1063-1072.

8. Nunes, R, Brandao, C., Rego, G. (2011). Public accountability and sunshine regulation. Health Care Anal 19; pp. 352-364.

9. OECD (2016), OECD Economic Outlook, Vol. 2016, Issue 1, Latvia, Available online: http://dx.doi.org/10.1787/eco_outlook-v2016-1-30-en.

10. OECD (2017). Health Policy in Latvia. OECD Health Policy Overview. Available online: http://www.oecd.org/els/health-systems/Health-Policy-in-Latvia-March-2017.pdf

11. Rechel, B., Wright, S., Edwards, N., Dowdeswell, B., McKee, M. (2009). Investing in hospitals of the future. Observatory studies No 16. European Observatory on Health Systems and Polcies, Copenhagen.

12. Romaniuk, P., Szromek, A. (2016), The evolution of the health system outcomes in Central and Eastern Europe and their association with social, economic and 
political factors: an analysis of 25 years of transition, BMC Health Services Research, pp. 16-95. Available online: DOI 10.1186/s12913-016-1344-3.

13. Sorenson, C., Drummond, M., Bhuiyan Khan, B. (2013). Medical technology as a key driver of rising health expenditure: disentangling the relationship. Clinico Economics and Outcomes Research: CEOR, 5, pp. 223-234. Available online: http://doi. org/10.2147/CEOR.S39634.

14. Taube, M., Mitenbergs, U., Sagan, A. (2014). The impact of the financial crisis on the health system and health in Latvia, the European Observatory on Health Systems and Policies, Publications, WHO Regional Office for Europe, Copenhagen.

15. Thimbleby, H. (2013). Technology and the Future of Healthcare. Journal of Public Health Research, 2(3), e28. Available online: http://doi.org/10.4081/jphr.2013.e28.

16. Van den Ven, W. P. M. M., Beck, K., Buchner, F., Schokkaert, E., Schut, F. T., Shmueli, A., Wasem, J. (2013), Preconditions for efficiency and affordability in competitive healthcare markets: Are they fulfilled in Belgium, Germany, Israel, the Netherlands and Switzerland? Health Policy 109, pp. 226-245.

17. World Health Organization (2018a). Health 2020: the European policy for health and well-being. Available online: http://www.euro.who.int/en/health-topics/healthpolicy/health-2020-the-european-policy-for-health-and-well-being.

18. World Health Organization (2018b). Multisectoral and intersectoral action for improved health and well-being for all: mapping of the WHO European Region, Governance for a sustainable future: improving health and well-being for all.

19. Zardo, P., Collie, A., Livingstone, A. (2014). External factors affecting decisionmaking and use of evidence in an Australian public health policy environment. Social Science \& medicine 108, pp. 120-127. 